\title{
Case Study: Incorporating International Themes Into The Business Curriculum At Missouri Southern State University
}

Janet Buzzard, (E-mail: Buzzard-b@mssu.edu), Missouri Southern State University Beverly Block, (E-mail: Block-b@mssu.edu), Missouri Southern State University

\begin{abstract}
Higher education is charged with preparing graduates to be successful in an international society. This paper will examine Missouri Southern State University's approach to internationalizing their campus and curriculum.
\end{abstract}

\section{INTRODUCTION}

onducting business beyond our borders has now become commonplace. Guffey (2006) cites three significant trends that have been taking place: (1) the globalization of markets, (2) technological advancements, and (3) an intercultural workforce. Higher education is faced with preparing graduates to be successful in an international society -- not only in the curriculum but in the way that education is being delivered. Missouri Southern State University has a unique approach to internationalizing their campus and curriculum.

\section{GLOBALIZATION OF MARKETS}

Doing business beyond our borders is now commonplace. Many companies are looking overseas as domestic markets mature. Companies can no longer expect double-digit sales growth at home (Guffey, 2006).

Another significant factor is the passage of favorable trade agreements. The General Agreement on Tariffs and Trade (GATT) promotes open trade globally, and the North American Free Trade Agreement (NAFTA) expands free trade among Canada, the United States, and Mexico. NAFTA created the largest and richest free-trade region on earth (O’Hara-Devereaux, and Johansen, 1994).

The European Union (EU) is a union of twenty-five independent states based on the European Communities and founded to enhance political, economic and social cooperation -- formerly known as European Community (EC) or European Economic Community (EEC). The following countries are part of the EU: Austria, Belgium, Cyprus (Greek part), Czech Republic, Denmark, Estonia, Finland, France, Germany, Greece, Hungary, Ireland, Italy, Latvia, Lithuania, Luxembourg, Malta, Netherlands, Poland, Portugal, Slovakia, Slovenia, Spain, Sweden, United Kingdom of Great Britain and Northern Ireland. The union of these countries is making a major impact on the world economy.

Ninnes and Hellsten (2005) state that globalization is a multifaceted phenomenon, and one of its major components is the internationalization of education. The increasing pace and complexity of global knowledge flows, and the accelerating exchange of educational ideas, practices and policies are important drivers of globalization. Higher education is a key site for these flows and exchanges.

\section{TECHNOLOGICAL ADVANCEMENTS}

Advancements in transportation, information, and communication technologies are major contributors to the development of our global interconnectivity. Supersonic planes carry goods and passengers to other continents overnight. 
The global economy is also being fueled by incredible advancements in communication technologies. The Internet allows instantaneous oral and written communication across time zones and continents. E-commerce allows companies to market their goods and services worldwide. Companies use the Web to sell products, offer services, provide support, investigate the competition, and link to suppliers.

\section{INTERCULTURAL WORKFORCE}

The evolution to an intercultural workforce is an important challenge for business and education. Because of increases in immigration, foreign-born persons are an ever-growing portion of the total U.S. population. Over the next 50 years, the population of the United States is expected to grow by nearly 50 percent, from about 275 million in the year 2000 to an estimated 394 million people in 2050. And two thirds of the increase will be due to net immigration according to the U.S. Department of Labor. Estimates also suggest that immigrants will account for half of all new U.S. workers in the years ahead (Gleckman, 1998).

Speck and Carmical state in their book Internationalizing Higher Education: Building Vital Programs on Campuses (2002) "Diversity is a buzz word in higher education, often characterized solely in ethnic or racial terms. Diversity, however, when properly understood, has a much wider scope; it can refer to cultural and linguistic diversity. Campuses can achieve greater diversity in the broadest sense by understanding how to internationalize higher education."

\section{IMPLICATIONS FOR HIGHER EDUCATION}

Business needs higher education to prepare students for their future careers in a constantly changing workplace. But the learning experience will need to change to prepare students for the ambiguous, constantly evolving workplace of tomorrow. Oblinger and Verville recommend in their book What business wants from higher education (1998) that "Business leaders find that recent graduates are deficient in the following areas, and the weaknesses must be addressed:

- $\quad$ Communication skills, both verbal and in writing

- $\quad$ Capability to work in teams, within individual areas and cross-functionally

- $\quad$ Flexibility and ability to accept ambiguity comfortably

- $\quad$ Ability to work with people from diverse backgrounds

- $\quad$ Understanding of globalizations and its implications

- Knowledge of ethical business practices"

To provide students with a more comprehensive introduction to the demands of the work world, students need to acquire skills that can be provided by extracurricular activities, internships, cooperative education experiences, and apprenticeships.

To educate students for competence and success in an interdependent world, the following ground rules have been proposed by the American Council on Education (ACE) for internationalizing institutions:

- $\quad$ Require that all graduates demonstrate competence in at least one foreign language

- $\quad$ Encourage understanding of at least one other culture

- $\quad$ Increase understanding of global systems

- $\quad$ Revamp curricula to reflect the need for international understanding

- $\quad$ Expand study abroad and internship opportunities for all students

- $\quad$ Focus on faculty development and rewards

- $\quad$ Examine the organizational needs of international education

- $\quad$ Build consortia to enhance capabilities

- $\quad$ Cooperate with institutions in other countries 
Higher education is faced with incorporating these techniques into the college experience. In order to prepare American students to compete in a worldwide workforce international competencies must be met. Missouri Southern State University has created a model for internationalizing their campus for their students and faculty.

\section{MISSOURI SOUTHERN STATE UNIVERSITY}

Missouri Southern State University (MSSU), located in Joplin, Missouri, is a state-supported, comprehensive university offering programs leading to the bachelor's degree and to selective collaborative master's degrees. Current enrollment is approximately 5,400. MSSU was one of the first post-secondary institutions in the state of Missouri to offer online courses and to offer entire degrees online. At this time, Missouri Southern offers bachelor's degrees online in Business Administration, Criminal Justice Administration, and General Studies. As of the spring of 2006, the number of students enrolled in Internet classes rose to 3,801, which is a 74 percent increase in less than four years. All indications show that online course, distance-only students, and the total number taking online classes at Missouri Southern State University will continue to rise.

\section{MISSION}

Missouri Southern State University has a statewide mission in international education granted to MSSU by special legislation. In July 1995, Missouri Governor Mel Carnahan signed into law House Bill No. 442, which directed that Missouri Southern "shall develop such academic support programs and public service activities it deems necessary and appropriate to establish international or global education as a distinctive theme of its mission."

The faculty and administration of Missouri Southern developed over the next year the outline of a comprehensive plan of international education. Included was the establishment of the Institute of International Studies, charged with overseeing the internationalizing of the campus.

\section{THEMED SEMESTERS}

The most distinctive aspect of Missouri Southern's effort to internationalize the curriculum, and the one with the most tangible effect throughout the campus community, has been the designation of "themed semesters." Each fall, a particular country or region of the world is selected to become the focus of intensive study. France is the theme for the Fall 2006 semester. Students and faculty attend guest lectures on topics dealing with socioeconomic, political, geographic, and cultural issues. Foreign film festivals are a regular part of the themed semester. Plays, food, and music festivals centered around the country are available. Field study trips to the country take place in the spring lasting for a couple of weeks. Faculty members sponsor the trips of up to 20 students where they earn 3 to 6 credit hours.

Missouri Southern was one of 13 U.S. colleges and universities included in Internationalizing the Campus 2004: Profiles of Success at Colleges and Universities, a major report published by NAFSA: Association of International Educators, for its themed semesters. Others included Duke University of North Carolina, Notre Dame, the University of Florida, and the University of Oregon. NAFSA believed MSSU's themed semesters to be unique and having the potential as a model for other campuses. The report showcases U.S. colleges and universities that are making innovative, wide-ranging efforts to integrate global approaches to teaching into campus learning.

\section{STUDY ABROAD PROGRAMS}

Study abroad programs also provide Missouri Southern students with additional opportunities to gain an understanding of other cultures and international issues. In 2006, students traveled to China, Costa Rica, England, France, Germany, Greece, Italy, Japan, Mexico, Russia, and Sweden under faculty supervision. Individually, students can spend an entire semester in such countries as Chile, China, England, France, Germany, Japan, the Netherlands, or Scotland through the International Student Exchange Program (http://www.isep.com) or Missouri Southern's bilateral agreements with universities around the world (http://www.mssu.edu/international/agreenew.htm). Other programs and activities designed to internationalize the university include: 
- $\quad$ Infusing the entire curriculum with a global perspective;

- $\quad$ Expanding the teaching of foreign languages to include new majors in French and German, new approaches, and new opportunities for language usage;

- $\quad$ Creation of dynamic majors in International Studies and International Business with uniquely designed courses;

- $\quad$ Increasing the participation of international students in campus activities.

Missouri Southern has received national recognition for its international mission, including the Theodore M. Hesburgh Award for Faculty Development to Enhance Undergraduate Teaching and Learning and an Andrew Heiskell Award for Innovation in International Education (http://www.iienetwork.org). The American Council on Education selected Missouri Southern as one of eight institutions from 57 applicants for an assessment project called "Promising Practices: Institutional Models of Comprehensive Internationalization (http://www.acenet.edu/AM/Template.cfm?Section=Activities\&TEMPLATE=/CM/ContentDisplay.cfm\&CONTENT

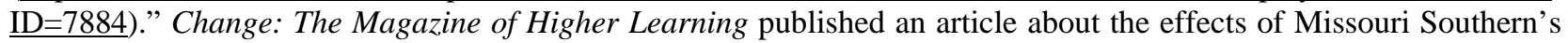
study abroad program in its May/June 2002 issue.

Senate Bill 55, which changed Missouri Southern State College's name to Missouri Southern State University-Joplin, also designated Missouri Southern as a statewide institution of international or global education. The bill was signed by Governor Bob Holden on July 12, 2003.

\section{SCHOOL OF BUSINESS ADMINISTRATION}

MSSU serves approximately 5,400 students with over 60 majors offered through four schools: Arts and Science, Business Administration, Education, and Technology. The School of Business Administration offers degrees in accounting, finance, general business, management, marketing, and international business. Approximately 40 full or part-time faculty and staff members serve around 900 students. MSSU is accredited by North Central and the School of Business Administration is accredited by ACBSP.

The International Business major is designed to prepare the graduate for employment with multinational companies. Potential employers may be local, regional, national, or international corporations. Courses include Global Business Literacy, International Business, International Business Cultural Exchange, International Marketing, International Management, International Accounting, International Corporate Finance, Internship in International Business, Advanced Topics in International Business, and Independent Study in International Business.

The School of Business Administration's mission is to assist students in the development of those intellectual, personal, and professional attributes which will prepare them to become global business leaders and exercise responsibility in the complex business environment of the future.

\section{SCHOLARLY ACTIVITIES}

Fulbright Scholars from other countries teach in the School of Business Administration on a regular basis. In most all business courses, international issues are addressed through case studies, research projects, and engaged learning exercises. Internships in other countries are encouraged and taken advantage by the students and sponsored by the faculty.

Faculty professional development funds are available for faculty members to lecture, conduct research, sponsor student field study trips, and travel to conferences abroad. Most faculty members are active in some or all of these international activities. 


\section{INTERNATIONAL TRADE AND QUALITY CENTER}

mission is to:

The International Trade and Quality Center is part of the School of Business Administration and their

- $\quad$ develop international consulting and other relevant services for four-state organizations and individuals who are or wish to be involved in international trade;

- $\quad$ assist area organizations in their quest for continuous improvement of products, processes, and services to enhance quality while reducing costs;

- $\quad$ enhance the business curriculum by providing international and quality resources, internship opportunities, and other appropriate assistance for faculty and students.

These objectives are met via assessment activities, research, educational programs, consulting, and serving as a clearinghouse for materials such as books, literature, tapes, and equipment.

The center provides assistance for local companies in internationalizing their operations. Networking among faculty, students, and prospective employers takes place through the center by workshops, speakers, and consulting opportunities.

\section{THE INTERNATIONAL BUSINESS CLUB}

The School of Business has an International Business Club for business majors. This student organization meets on a regular basis and its membership includes domestic and international students studying business at Missouri Southern. Speakers from multinational companies speak on a variety of topics. Former Missouri Southern business graduates working in the international area network and mentor current students interested in working abroad.

All of these activities happening on Missouri Southern State University's campus foster a rich learning environment and experience for all graduates, whether they will choose to work in the United States or abroad. Hopefully, their higher education learning experience will give them the skills to be successful and contribute to our global society in a meaningful way.

\section{REFERENCES}

1. Futurework: Trends and Challenges for Work in the $21^{\text {st }}$ Century, U.S. Department of Labor. Retrieved on August 6, 2006, from: http://www.dol.gov/_sec/gils/records/000187.htm.

2. Gleckman, H. (1998). A rich stew in the melting pot. Business Week, 31 August, 76.

3. Guffey, M. E. (2006). Business communication: Process and product ( $5^{\text {th }}$ ed.). Mason, OH: South-Western.

4. Ninnes, P., \& Hellsten, M. (2005). Internationalizing Higher Education Critical Explorations of Pedagogy and Policy Series: CERC Studies in Comparative Education, Vol. 16.

5. $\quad$ Oblinger, D., \& Verville, A. (1998). What business wants from higher education. Phoenix: The Oryx Press.

6. O’Hara-Devereaux, M., \& Johansen, R. (1994). GlobalWork: Bridging distance, culture, and time. San Francisco: Jossey-Bass.

7. $\quad$ Speck, B., \& Carmical, B. (2002). New Directions for Higher Education, No. 117. 
NOTES 